\title{
Developing the communicative-pragmatic competence in the training of the Russian linguistics bachelor students
}

\section{Развитие коммуникативно-прагматической компетенции в обучении бакалавров лингвистики в России}

Received: January 10, 2021
Accepted: March 2, 2021

Written by:

A.V. Lebedev ${ }^{47}$

https://orcid.org/0000-0001-8193-8655

S.V. Bespalova ${ }^{48}$

https://orcid.org/0000-0003-0529-6608

I.S. Pinkovetskaia ${ }^{49}$

https://orcid.org/0000-0002-8224-9031

\begin{abstract}
The development of the oral and written skills in the practice of teaching foreign languages in the Russian linguistic higher institution pays the major attention to the construction of monologic and dialogical statements without focusing on the pragmatic factors of communication. When mastering language expressions, students do not always correlate them with the specific communicative tasks in a certain situation of foreign language communication, which is due to the ignorance of the pragmatic component. Meanwhile, the correct correlation and use of linguistic units in the process of foreign language communication (adequate to a given situation and intentions) is extremely important at the first or second (freshman and sophomore) years of higher education, when students primarily master the skills of the correct expression means. However, in teaching foreign languages (e.g., German and English), there is a disregard for such pragmatic factors as: setting and defining intentions, social roles and focusing on the interpersonal relations of communicants, targeted communication; isolation of the communicative competence from the pragmatic issues; insufficient study of the discourse content and structure as the means of teaching foreign languages in conjunction with pragmatic characteristics. The authors propose their own methodology for the development of the communicative-pragmatic competence under the
\end{abstract}

\begin{abstract}
Аннотация
При развитии устных и письменных навыков в практике преподавания иностранных языков в российском лингвистическом вузе основное внимание уделяется построению монологических и диалогических высказываний без акцентирования внимания на прагматических факторах общения. При овладении языковыми выражениями, студенты не всегда соотносят их с конкретными коммуникативными задачами в определенной ситуации иноязычного общения, что обусловлено незнанием прагматического компонента. Между тем правильное соотношение и использование языковых единиц в процессе иноязычного общения (адекватное данной ситуации и намерениям) чрезвычайно важно на первом или втором курсах высшего образования, когда студенты в первую очередь овладевают навыками правильного выражения мыслей. Однако при обучении иностранным языкам (например, немецкому и английскому) игнорируются такие прагматические факторы, как: постановка и определение намерений, социальные роли и ориентация на межличностные отношения коммуникантов, целенаправленное общение; оторванность коммуникативной компетенции от прагматических вопросов; недостаточная изученность содержания и структуры дискурса, как средства обучения
\end{abstract}

\footnotetext{
${ }^{47}$ Foreign Languages Department, Chair of English for Professional Communication N. P. Ogarev Mordovia State University, Saransk, Russia.

${ }^{48}$ Foreign Languages Department, Chair of German Philology N. P. Ogarev Mordovia State University, Saransk, Russia.

${ }^{49}$ Economic analysis and state management Department, Ulyanovsk State University, Ulyanovsk, Russia.
} 
conditions of training the prospective bachelors of linguistics. Research methods include systematic approach, provisions of the interdisciplinary approach, competence-based approach, comparative method, modeling method. The communicative-pragmatic model of teaching foreign languages presented in this article has confirmed its effectiveness for the development of oral and written speech practice among bachelor students of the linguistic university. The introduction of the developed methodology will increase the level of the language proficiency and the degree of formation of the students communicative-pragmatic competence by motivating and expanding their speech capabilities.

Key Words: foreign languages teaching organization, model, communicative-pragmatic competence, discourse, socio-cultural and intentional markers. иностранным языкам в сочетании с прагматическими характеристиками. Авторы предлагают собственную методику развития коммуникативно-прагматической

компетенции в условиях подготовки будущих бакалавров лингвистики. Методика исследования основывалась на системном подходе, положениях междисциплинарного подхода, компетентностном подходе, сравнительных методах, а также моделировании. Представленная в данной статье коммуникативно-прагматическая модель обучения иностранным языкам подтвердила свою эффективность для развития устной и письменной речевой практики студентов-бакалавров лингвистического вуза. Внедрение разработанной методики позволит повысить уровень владения языком и степень сформированности коммуникативнопрагматической компетенции студентов за счет мотивации и расширения их речевых возможностей.

Ключевые слова: обучение иностранным языкам, модель, коммуникативнопрагматическая компетенция, дискурс, социокультурные и интенциональные маркеры.

(Baldegger, Müller \& Schneider, 1989; Zertifikat Deutsch, 2011).

In our opinion, the identification of the pragmatic component allows to ensure the successful communicative interaction of language partners. The process of teaching foreign languages implies that students are to be guided towards the adequate use of language means to implement the so-called perlocutionary effect in communication.

The above-stated provisions allow to consider the communicative and pragmatic competence not as a part-whole correlation, but as the elements of the equal value, complementary and conditional in relation to each other. As the authors suggest, this is a strong argument for substantiating the concept of "the communicative-pragmatic competence" that can be defined as the ability to correlate communicative intentions with linguistic means at the receptive and reproductive levels in order to have an impact and be effective in everyday communication. 
The need for the communicative-pragmatic competence formation as one of the goals of the bachelor students language training is defined by the existing contradiction between the underestimation of the pragmatic linguistics nomenclature in the theory and methodology of teaching foreign languages and the requirements of the third-generation Federal State Educational Standard (FSES) describing the expected results of mastering the curriculum for the bachelor's degree in the field of Linguistics (profile: "Theory and practice of teaching foreign languages and cultures"). The given standard provides for the formation of general cultural, professional competencies and expertise that focus on the advanced specialists training in the area of foreign languages, which is defined by the requirements of the current labor market.

In this regard, it is necessary to highlight the competencies significant in mastering the social and pragmatic factors of foreign language communication:

- the knowledge of ethical and moral norms adopted in a foreign culture; willingness to use the models of social situations, typical scenarios of interaction between the participants of intercultural communication;

- the mastery of the major discourse tools to achieve the communicative goals of a certain utterance in relation to the peculiarities of the current communicative context (time, place, goals and conditions of interaction);

- the mastery of the main tools for expressing the semantic, communicative and structural continuity between the parts of an utterance - the compositional and structural text elements (introduction, main part, conclusion), collocations and sentences;

- the ability to freely express individual thoughts, adequately applying a variety of language means in order to highlight the relevant information;

- the competence in the features of the official, neutral and informal registers of communication;

- the readiness to overcome the influence of stereotypes and conduct intercultural dialogue in the general and professional spheres of communication;

- the ability to use etiquette cliches in oral and written communication (Federal state educational standard, 2014).

This article puts forward the basic principles of organizing education with the inclusion of the pragmatic and socio-cultural markers of the German- and English-language discourse.

\section{Literature Review}

Although most researchers agree on the multicomponent nature of communicative competence, the academic literature and methodological guidelines feature a variety of viewpoints regarding the communicationoriented content of teaching foreign languages. The ideas about the predominance of a certain component differ significantly (Bespalova, 2003; Bim, 2001; Safonova, 1992; Solovova, 2002). The authors consider the major competences: linguistic, speech (frequently titles as "pragmatic") (Ek \& Trim, 2012), sociocultural or sociolinguistic (Ulrich, 1979). The Council of Europe developed the documents on Language Policy, listing the components of the communicative competence: linguistic, sociocultural and pragmatic (Common European framework, 1996; Zertifikat Deutsch, 2011).

It is undoubtedly important that there is a pragmatic component in the structure of the communicative competence. However, it should be noted, that some scholars hold the opinion that the concept of "pragmatic" can be used as a synonym for the notion of "communicative", since the impact on the addressee is of paramount importance (Piepho, 1979). In our opinion, the broadest concept is the notion of communication; in other words, the concept of pragmatics is covered by the concept of communication. However, this does not call into question the validity of the simultaneous existence of these terms. In this regard, McCroskey (1985) suggests the profound thesis distinguishing the function of influence (i.e. changing the ideas, perceptions and attitudes of a communication partner) among the communicative process functions. The idea is confirmed by the study of Stepanov (1981), who defines pragmatics as a system of means and techniques used to achieve the authors' goals "for the sake of influencing a listener in order to convince and motivate, etc.". Analyzing these propositions through the prism of linguodidactics, it becomes obvious that the academic theory and practice demand to highlight the pragmatic competence along with its communicative counterpart.

In our opinion, the pragmatic and functional approach of the researchers Neuner \& Hunfeld (1993) serve as the fundamental concept for organizing the training with a focus on pragmalinguistics, which constitutes the following 
principles: the linguistic implementation of the set communicative tasks; the choice from the available language tools depending on a certain situation and context; achieving the expected impact on the communication partner. These ideas are widely recognized among the Russian linguists and methodologists (Argustanyants, 1982; Astafurova, 1997; Baskova, 1992; Gorodnikova \& Dobrovolskiy, 2001; Nabieva, 1996).

Teaching the English language through the prism of the pragmatic and linguo-didactic competence has been in focus of multiple international researchers. For instance, the study by Onalan \& Cakır (2018) investigates "the pragmatic language behavior of Turkish learners of English in formal complaint situations through the comparison of their speech act performances to those of native speakers". In the survey titled "Understanding pragmatics in second-language learning. A few linguistic preliminaries", Torricelli (2018) from the University of Messina analyzes learning pragmatics in the secondlanguage which is believed to become a natural procedure only if it follows the implicit strategy when learning a language is to deal with the historical typology of metaphorical thought acquiring the automatic approach to its linguistic means. The study by Sousa (2017) argues that a pedagogical stylistics approach to English as a foreign language teaching/learning develops students' linguistic competence and raises their awareness as to the meaning making potential of language in use in the texts at hand taking into account their larger historical and sociocultural settings. Lebedev et al. (2020) offer the description of English for Specific Purposes (ESP) course implementation in the Russian higher educational institutions. The authors study the experience of ESP training at Ogarev Mordovia State University (Saransk, Russia) and outline the most typical issues faced by ESP teachers in real-life conditions of education process from the pragma-linguistic standpoint, shifting from the theoretical linguistics to the linguistics applied.

The existing studies in the fields of linguistics, the theory and methodology of teaching foreign languages, the issues of teaching oral and written communication, speech interaction and the integration of pragma-linguistics into the content of teaching foreign languages consider the following aspects:

- the communicative and pragmatic aspects of linguistic phenomena (Anisimova, 1988; Belyaeva, 1988; Bezukladova, 1999;
Bykova, 1997; Gorlyakov, 2001; Komina, 1984);

- the development of interpersonal skills (Drokina, 1996; Rumyantseva, 1999; Smirnova, 1999);

- the strategies of communicative behavior (Andrushko, 1990; Astafurova, 1997; Issers, 1999);

- the development of the communicative competence in multimedia and innovative technologies and tools (Bespalova \& Kuznetsova, 2009; Gez, 1985; Milrud \& Maksimova, 2000; Ponutrieva, 1997; Volovik, 1988; Zhoglina, 1998).

Despite the promising nature of these concepts and approaches, it should be emphasized that the issues of the complex consideration of pragmatic factors in the practice of teaching foreign languages remain outside the researchers` field of vision, thus demanding the further study on the mechanisms of communication and its dynamics. In addition, excessive pre-occupation with the pragmatic texts, as well as ignoring the student's individual culture, frequently face criticism.

\section{Materials and Methods}

Setting the goals and objectives for the given study resulted in the implementation of a set of approaches. One of the priorities is the systematic approach, which allows to determine the range of problematic issues and methodological challenges of this study. The applied interdisciplinary approach reflects the synergy of linguo-didactic, linguistic and pragmatic theories.

The teaching content proposed by the authors for the preparation of the linguistics bachelor students is based on the competence-based approach, which results in applying its principles according to the third generation Federal State Educational Standard for Higher Education (Order No 940/2014). The standards provide for the formation of cultural, professional and expert competencies that focus on training specialists to acquire the advanced knowledge in foreign languages considering the paradigm of continuous education of the "linguistic personality".

The comparative method allows to focus on the juxtaposition of the profound domestic and international experience in the social sciences field, comparing the major professional educational curriculums in the area of linguistics. 
The modeling method is effectively implemented at the stage of practically applying the communicative-pragmatic learning model, which allows to simulate the communicative situations of the foreign language speech, as well as to master various types of discourses and the principles of their construction based on the parameters of the communicative situation.

The modeling method is implemented at the stage of testing the effectiveness in the course of the application of the communicative-pragmatic organization of training. It is viewed as a simulation of communicative situations, carried out in real-life communication conditions. Within the framework of this research, the modeling of situations involves the classroom imitation of foreign language communication based on such pragmatic communication factors. The application of this technology in teaching practice allows students to more successfully establish and maintain foreign language communication, considering such parameters of the situation as: communicative roles, speaker's intention, social status, the degree of relationships between communicants, the given speech samples for the implementation of the communicative intention. The advantages of the modeling method are as follows: students are immersed into the authentic communication conditions, they are able to stimulate their speech activity and motivation, as well as achieve a more rapid perlocutionary effect. The implementation of this method in the educational process confirms the effectiveness in focusing on the presented teaching model and contributed to the formation of foreign language communicativepragmatic competence in students and the successful mastering of dialogical discourse.

\section{Research Results}

The research substantiates the content of the communicative-pragmatic organization of training, allows to determine the methodological tools and identifies the following major and vital theoretical prerequisites:

1. The development of pragma-linguistics focuses on the demand in the knowledge of the pragmatic mechanism of communication and its dynamics (establishment, maintenance and the completion of contact in discourse), as well as their consideration in the theory and practice of teaching a foreign language.

2. The speech acts theory aims at the study of speech acts as elementary units of communication and learning, its perception, construction and interpretation. The content of teaching a foreign language should include various types of speech acts, taking into account their distribution by stages of training.

3. Interpersonal verbal communication implies the mandatory presence of a speaker and a listener - "addresser" and "addressee", which are the two sides of the communicative act and constitute the participants in the discourse, acting as the carriers of certain social roles.

4. Acting as a category of pragma-linguistics, presupposition is the awareness of a speech act context, which is critical for its understanding and generation. This knowledge is an inherent condition for the success of learning foreign language communication.

5. Anthropocentrism stimulates the inclusion of an individual in the use of foreign languages and its analysis, which emphasizes the significance of the human factor. In the learning process, this is reflected in the development of a linguistic personality through a foreign language and culture.

These theoretical premises stress the importance of pragmatic markers in the content of teaching foreign language oral and written communication and serve as the basis for creating this communicative-pragmatic model that stimulates the students` need to use their language skills not only for the implementation of communicative goals, but also for raising the cognition in communication. The pragmatic-functional concept elaborated by didactics experts Neuner \& Hunfeld (1993) serves as the basis for the proposed organization of training. The fundamental principles of the concept are as follows: linguistic implementation of the set communication tasks; the choice of the available language tools depending on the pragmatic situation; achieving the required impact on the communication partner.

Having considered the urgent demand in the communicative-pragmatic organization of teaching a foreign language, we also need to address such a communicative phenomenon as the dialogical discourse, which provides the possibility to study the pragmatic mechanism of communication and its dynamics within the theory and practice of teaching a foreign language, and reflects the connection between language and culture. It includes an entire 
complex of communicative and pragmatic elements, such as the setting and implementation of intentions, the relationship between "the speaker" and "the listener", the social roles, the nature of interpersonal relations etc.

As compared to the notion "text", "discourse" is a broader and more dynamic concept, since it includes extralinguistic means and social context. The text, however, is a more static concept, because it is defined as the result of speech-thinking activity; while the discourse is both the result and the process of this activity.

The social and pragmatic aspects act as the major elements characterizing the content of the communicative-pragmatic organization of teaching foreign languages in a linguistic higher institution (Fig. 1).

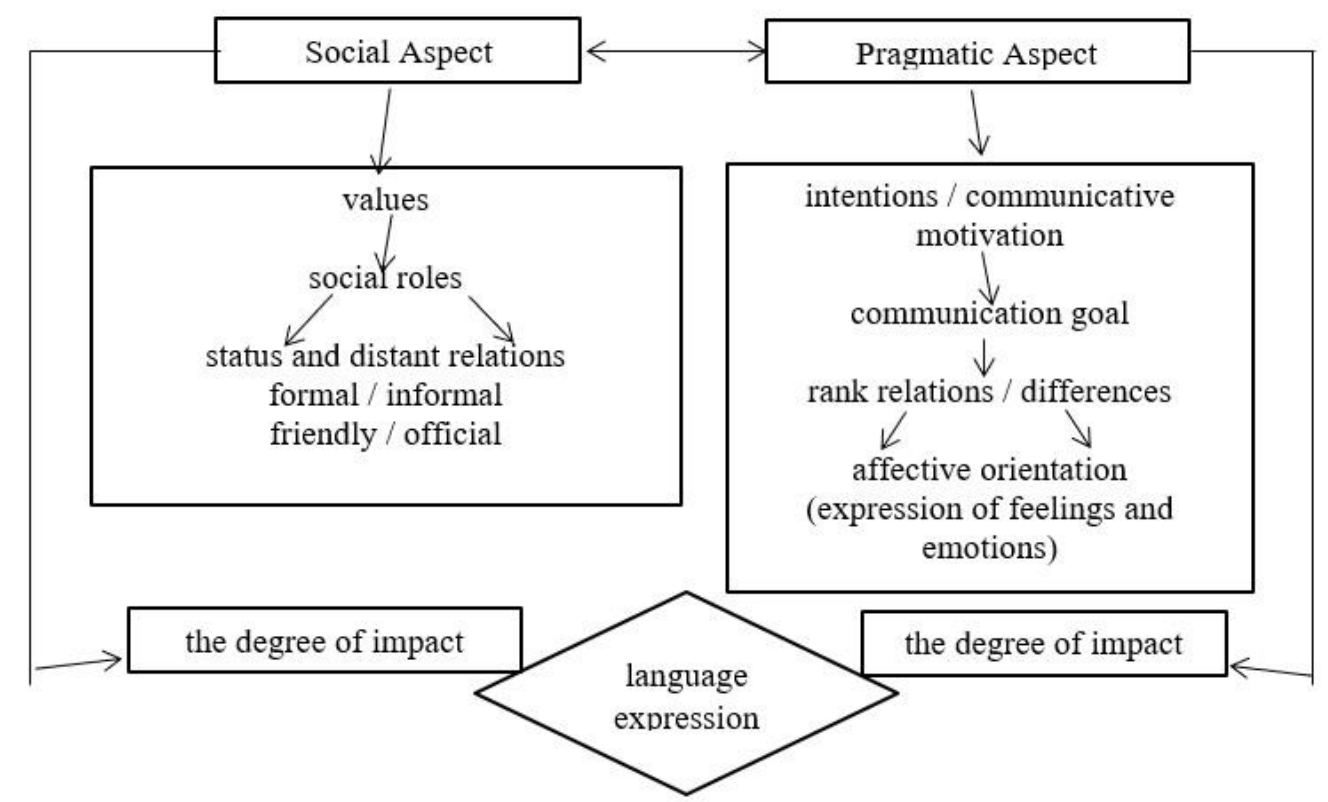

Fig. 1. Communicative and pragmatic organization of teaching foreign languages (by S.V. Bespalova)

The discourse social and pragmatic distribution provides the possibility to single out such characteristics as intentional and sociocultural marking. The intentional discourse marking implies the existence of a certain relevant communicative intentions sets, implemented depending on specific conditions. The sociocultural discourse marking is the correlation of discourse with specific participants in the act of communication, their social status, composition, degree / proximity of communicants, their role relationships, as well as the complex of communicative and pragmatic norms. The norms regulate the course and nature of the major communication parameters, which determine the structure and rules in the process of discourse, namely: the situation type, the subject of communication, the type of speech act, intention, communicative goal, i.e., the communicative and pragmatic aspects of communication. One can also note that the awareness of the foreign language communication norms is critical for the selection of behavioral tactics, as well as for understanding the communicants, which is the result of communication.

In the procedural sense, the core of the proposed communicative-pragmatic model contains the intentional, interactive and affective learning strategies; their integrated development results in the formation of the communicative-pragmatic competence and mastery of discourse. The given teaching strategies are matched to the corresponding actions and presented in the tables.

The intentional strategies focus on the development of recognition actions (receptive level) and linguistic implementation (reproductive level) of communicative intention in discourse. 
Table 1.

Intentional Strategies.

\begin{tabular}{|c|c|}
\hline Strategies: & Actions: \\
\hline $\begin{array}{l}\text { *Understanding of the communicative } \\
\text { intention based on the analysis of the } \\
\text { linguistic means and the expression of } \\
\text { a response in confirmation. }\end{array}$ & $\begin{array}{l}* \text { Recognize the communicative intention of the interlocutor based on } \\
\text { the analysis of linguistic means. } \\
* \text { Express a response to the words of the interlocuto } \\
* \text { Start, maintain and complete communication in accordance with the } \\
\text { speech rules of a language. }\end{array}$ \\
\hline $\begin{array}{l}\text { *Determination and linguistic } \\
\text { implementation of the personal } \\
\text { communicative intention. }\end{array}$ & $\begin{array}{l}\text { * From the range of the studied speech techniques, choose the tools } \\
\text { valid for the communicative intention and communication situation } \\
\text { (request the necessary information, describe, report: (by mail, in a store, } \\
\text { in a cafe). } \\
\text { * Express the personal communicative intention clearly, freely and } \\
\text { fluently. } \\
\text { * Build an individual's utterance that is adequate to the communicative } \\
\text { task being solved and to the structural features of the discourse type. } \\
\text { * Use formulas of speech etiquette in situations of establishing, } \\
\text { maintaining and terminating of a speech contact. }\end{array}$ \\
\hline $\begin{array}{l}\text { *Impact on the } \\
\text { communication partner } \\
\text { and successful } \\
\text { establishment of a } \\
\text { speech contact. }\end{array}$ & $\begin{array}{l}\text { *Apply the necessary options for the linguistic } \\
\text { implementation of the communicative intention in order to } \\
\text { achieve the expected goal / reaction from an interlocutor. }\end{array}$ \\
\hline
\end{tabular}

The purpose of interactive strategies is to establish contact between communicants, the ability to act as a listener ("addressee") and a speaker ("addresser"), observing the rules and norms of a given discourse. This type of strategy determines the nature of the communicants interpersonal interaction, which largely determines the outcome of communication.

Table 2.

Interactive Strategies.

\begin{tabular}{|c|c|}
\hline Strategies: & Actions: \\
\hline $\begin{array}{l}\text { *Identifying the communicative } \\
\text { portrait of a communication partner }\end{array}$ & $\begin{array}{l}\text { *Determine the communicative portrait of a communication partner(s) } \\
\text { (age / gender / status / rank / degree of acquaintance) } \\
\text { Establish verbal contacts with an interlocutor through social expressions } \\
\text { of greeting, introduction, expression of gratitude, farewell, etc. }\end{array}$ \\
\hline $\begin{array}{l}\text { *Determining the sociocultural } \\
\text { background of a context / situation. }\end{array}$ & $\begin{array}{l}\text { *Use the speech etiquette and the communicative tactics of } \\
\text { communication, depending on the conditions and the socio-cultural } \\
\text { background of a situation. }\end{array}$ \\
\hline $\begin{array}{l}\text { *Sequential change in the perspective } \\
\text { of the participants roles in the } \\
\text { discourse (speaker-listener) }\end{array}$ & $\begin{array}{l}\text { * Comprehend and complement a partner's thought; actively respond to } \\
\text { the statements of the communication partner; take the initiative in case of } \\
\text { a communication failure. } \\
\text { In case of incomplete understanding, question and clarification methods } \\
\text { are used. }\end{array}$ \\
\hline $\begin{array}{l}\text { *Structural-semantic anticipation and } \\
\text { the speech strategy building of a } \\
\text { given discourse. }\end{array}$ & $\begin{array}{l}\text { *Predict communicative motions and build a potential strategy for } \\
\text { conducting one or another type of discourse. }\end{array}$ \\
\hline $\begin{array}{l}* \text { Speech mobility in the changing } \\
\text { communicative conditions of a } \\
\text { discourse or its type. }\end{array}$ & $\begin{array}{l}\text { *Vary verbal and non-verbal behavior in the changing conditions of a } \\
\text { foreign language communication. If necessary, change the strategy of } \\
\text { verbal behavior itself, using linguistic means and adequate situations. }\end{array}$ \\
\hline $\begin{array}{l}\text { *Considering the nature of } \\
\text { interpersonal relations and the choice } \\
\text { of linguistic means corresponding to } \\
\text { a situation of communication. }\end{array}$ & $\begin{array}{l}\text { *Provide the communicative correction of inappropriate speech behavior, } \\
\text { resolve challenging speech conflicts, overcome them, showing politeness } \\
\text { and tactfulness. } \\
\text { *Determine the social roles and nature of the communicants` relationship } \\
\text { and accordingly select the language means. }\end{array}$ \\
\hline $\begin{array}{l}\text { *Observance of the necessary } \\
\text { distance in communication. }\end{array}$ & $\begin{array}{l}\text { * Maintain the necessary distance with an interlocutor, showing politeness } \\
\text { and tactfulness. }\end{array}$ \\
\hline
\end{tabular}


The affective strategies are applied to teach the non-verbal (especially the emotional) element of the discourse, that acts as a regulator of the communicants` behavior. Emotions complement the linguistic means of communication, affect and enhance the power of communication, largely determining its result. The proposed strategies correspond to the actions presented below.

Table 3.

Affective Strategies.

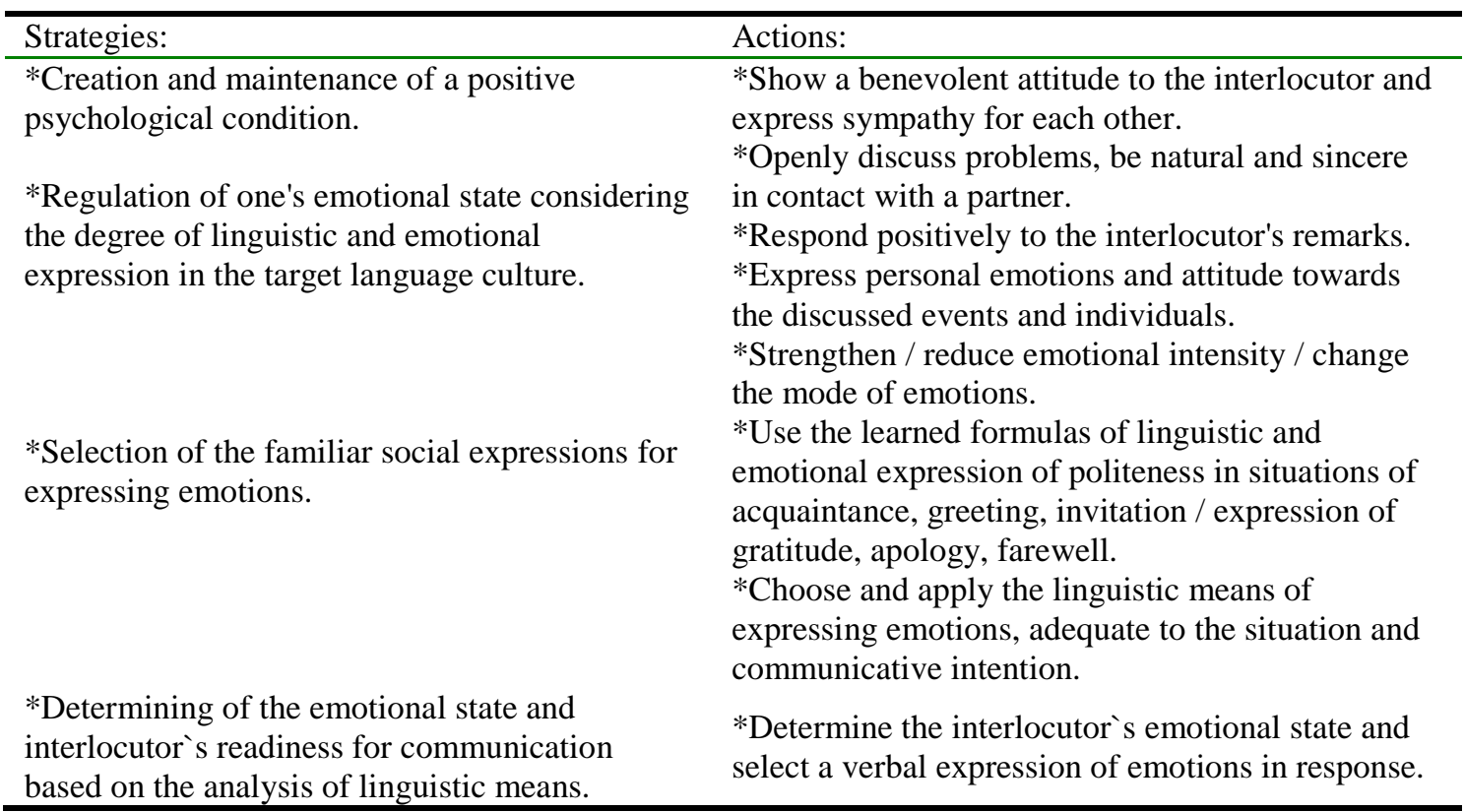

Along with the selected learning strategies, the listed aspects constitute the content and procedures of the communicative-pragmatic organization of teaching foreign languages, aimed at the formation of the communicativepragmatic competence, i.e., the ability to appropriately express the communicative intention in order to achieve the goal of communication.

\section{Discussion}

It is widely recognized that the major goal of teaching the foreign language communication is the formation of the communicative competence in students. As shown by the practice of teaching foreign languages, there is a current demand in supplementing this type of competence. This element should be included in the structure and pragmatic competence, along with the linguistic, discursive and sociocultural component of this concept. This is primarily conditioned by the fact that pragmatic factors of communication prepare students to imitate the communicative situations that are close to authentic conditions. The awareness and mastery of such pragmatic factors of communication as: intention / communicative motivation, the purpose of the statement, social roles and ranks of communicants, affective mood (emotional state) and the degree of impact (perlocutionary effect) significantly increases the effectiveness of teaching foreign languages and the implementation of foreign language communication. This served as the basis for the development of the communicative-pragmatic organization of teaching foreign languages in the system of training bachelors of linguistics taking into account the requirements of modern standards in language education.

The feasibility and the effectiveness of the developed methodological concept are shown by its implementation into the teaching practice in the junior courses of the Foreign Languages Department at the National Research Mordovia N.P. Ogarev State University (the field of training - Linguistics). The foreign language communication is aimed at developing speech practice and the formation of communicativepragmatic competence among bachelor students at a linguistic university. The application of the given methodology is able to solve the problem of intensifying teaching foreign languages by increasing motivation and expanding the speech capabilities of students.

The prospect of the developed methodology can be explained by the fact that it can be 
implemented in the practice of teaching in relation to any foreign language. The research done, however, does not cover the variety of problems associated with the communicativepragmatic organization of teaching a foreign language itself and a foreign language discourse in general. For instance, outside the scope of this study are the issues on the role of monological discourse and the typology of discourses, as well as their place in the educational process. These issues are very significant in the course of teaching the foreign language communication and demand further academic and experimental development.

\section{Conclusion}

The identified major results of the study include the following:

1. The basic provisions of the pragmalinguistic direction, anthropocentrism, the theory of speech acts, the content of interpersonal verbal communication and sociolinguistics serve as the fundamental theoretical prerequisites for the development of the communicative-pragmatic organization in teaching foreign languages.

2. The study reveals and substantiates the content and procedural aspects of the communicative-pragmatic learning model in the field of foreign languages. The model also includes and involves the intentional, interactive and affective strategies, as well as the actions for the formation of communicative-pragmatic competence through various exercises and assignments.

3. The comparison of the concepts "discourse" and "text" allows to conclude that discourse is a more dynamic concept, since it includes the text itself and the extralinguistic factors of communication. Traditionally acting as a unit of learning, the text does not fully reflect the parameters of verbal communication that should be considered in the educational process. In the theory and practice of teaching foreign languages, the concept of discourse possesses the following advantages: 1) it disproves the idea of the written speech dominance, which is frequently typical of a text; 2) it clearly shows the difference between two levels of linguistic structures: grammatical and discursive (the presence of extralinguistic parameters); 3) it draws attention to the minimum unit of communication, which is a speech act, not a sentence.
4. The developed model highlights the social and motivational aspects related to the incentive / communicative intention of the participants in the discourse, the orientation on the social roles of communicants, the degree of their acquaintance, the proximity / distance of relations, ritual and etiquette forms, taking into account the communicative-pragmatic norms. These factors determine the nature of the individual communicative behavior.

5. Procedurally, the teaching content of the communicative-pragmatic model highlights the intentional, interactive and affective learning strategies; their combined and integrated development leads to the formation of the communicative-pragmatic competence and mastery of the dialogical discourse. The intentional strategies focus on the development of the skills regarding the recognition and linguistic implementation of the intentions in discourse. The purpose of the interactive strategies is to establish contact between communicants, the ability to act as a speaker ("addresser") and a listener ("addressee"), observing the rules and norms of the discourse. This type of strategy determines the nature of the communicants` interpersonal relations. Teaching the emotional aspects of discourse requires the affective strategies that regulate the behavior of the participants in the discourse. The emotions complement the linguistic means of communication, enhancing and strengthening the power of communication, and largely determine its result.

\section{References}

Andrushko, S. Ya., (1990). Methods of teaching oral and speech communicative activity on a situational basis in groups of in-depth study of the English language (dissertation of the candidate of pedagogical sciences). Odessa State University, Odessa, Ukraine, 217 p.

Anisimova, E.E., (1988). Communicativepragmatic norms. Philological sciences, 6. 64-69. Recovered from: https://clck.ru/TWk36

Argustanyants, E.S., (1982). Teaching dialogic speech in situations of role behavior, (dissertation of the candidate of pedagogical sciences), Moscow State University, Moscow. $212 \mathrm{p}$.

Astafurova, T.N., (1997). Strategies of communicative behavior in professionally significant situations of intercultural communication: (dissertation of the candidate of 
pedagogical sciences), Volgograd State University, Moscow. 324 p. Recovered from: https://www.dissercat.com/content/strategii-

kommunikativnogo-povedeniya-v-

professionalno-znachimykh-situatsiyakh-

mezhkulturnog

Baldegger, M., Müller, M. \& Schneider, G. (1989). Kontaktschwelle Deutsch als Fremdsprache (Contact threshold for German as a foreign language). Berlin, München: Langenscheidt. 152 p.

Baskova, M.E., (1992). Pragma-linguistic and the interactive expressions of disagreement (based on the material of modern English dialogue): (dissertation of the candidate of pedagogical sciences), Saint-Petersburg State University, Saint-Petersburg. 179 p.

Belyaeva, E.I., (1988). Modality and pragmatic aspects of directives in modern English, (dissertation of the Doctor of Philology), Moscow State University, Moscow. 423 p.

Bespalova, S.V. (2003). Communicativepragmatic strategies in teaching foreign language communication at language university. Materials of the VIII scientific conference of young scientists of the Ogarev Mordovia State University. In 3 parts. 135-136. Recovered from: https://elibrary.ru/item.asp?id=23311162\&pff=1 Bespalova, S.V. \& Kuznetsova, L.N. (2009). Video im Deutschunterricht: study guide. Manual. Saransk: Publishing house of Mordovia State University. 48 p. Recovered from: https://elibrary.ru/item.asp?id=25074647

Bezukladova, I.Yu. (1999). Communicative and pragmatic features of the functioning of some forms of personalization in the German language, (dissertation of the candidate of philological sciences). Tambov State University, Tambov. 165 p. Recovered from: https://www.dissercat.com/content/kommunikat ivno-pragmaticheskie-osobennosti-

funktsionirovaniya-nekotorykh-form-

personalizatsi

Bim, I.L. (2001). Some relevant problems of modern teaching foreign languages. Foreign languages at school. 4. 5-7.

Bykova, I.A. (1997). Communicative-pragmatic analysis of non-equivalent and background vocabulary of the Spanish language, (dissertation of the candidate of philological sciences), Moscow State Pedagogical University, Moscow. $175 \mathrm{p}$.

Council of Europe (1996). Common European framework of reference for languages: learning, teaching, assessment. Language Policy Unit, Strasbourg. 167 p. Recovered from: https://rm.coe.int/16802fc1bf
Drokina, S.V. (1996). Development of interpersonal communication skills in the process of professional training of students of technical universities, (dissertation of the candidate of pedagogical sciences), Togliatti State University, Togliatti. 194 p. Recovered from: https://www.dissercat.com/content/razvitienavykov-mezhlichnostnogo-obshcheniya-vprotsesse-professionalnoi-podgotovki-student Ek van, J.A., Trim, J.L.M. (2012). Waystage. Council of Europe Conseil de l'Europe. Cambridge University Press. 156 p.

Gez, N.I. (1985). Formation of the communicative competence as an object of foreign methodological research. Foreign languages at school. 2. 19-23.

Gorlyakov, P.Yu. (2001). Pragmatically oriented teaching of communication in English in educational institutions, (dissertation of the candidate of pedagogical sciences), SaintPetersburg State University, Saint-Petersburg. 266 p. Recovered from: https://www.dissercat.com/content/pragmatiche ski-napravlennoe-obuchenie-bshcheniyu-naangliiskom-yazyke-v-pervom-klasse-obshc Gorodnikova, G.D. \& Dobrovolskiy, D.O. (2001). German-Russian dictionary of speech communication. 4th ed., Stereotype. Moscow: Russian language. $332 \mathrm{p}$.

Issers, O.S. (1999). Communicative strategies and tactics of Russian speech (dissertation of the candidate of pedagogical sciences), Omsk State University, Omsk. 560 p. Recovered from: https://www.dissercat.com/content/kommunikat ivnye-strategii-i-taktiki-russkoi-rechi

Komina, N.A. (1984). The communicativepragmatic aspect of English dialogical speech, (dissertation of the candidate of philological sciences). Taras Shevchenko National University of Kyiv, Kyiv. 243 p. Recovered from: https://www.dissercat.com/content/kommunikat ivno-pragmaticheskii-aspekt-angliiskoidialogicheskoi-rechi

Lebedev, A., Pinkovetskaia, I., Rozhkov, M. \& Tsybina, L. (2020). Teaching English in the higher education institution: teachers and students perspective. Amazonia Investiga, 9(25). 190-199. Recovered from: https://amazoniainvestiga.info/index.php/amazo nia/article/view/1050

McCroskey, J.C. (1985). Communication: Apprehension, Avoidance and Effectiveness. Scottdale, Ariz: Corsuch Scorisbrick. 121 p. Milrud, R.P. \& Maksimova, I.R. (2000). Modern conceptual principles of communicative learning in foreign languages. Foreign languages at school. 4. 9-16.

Nabieva, V.M. (1996). The pragmatic aspect of the discourse of modern liturgical sermon 
(author's abstract of thesis for the candidate of philological sciences), Moscow State University, Moscow. 17 p.

Neuner, G. \& Hunfeld, H. (1993). Methoden des Fremdsprachlichen Deutschunterrichts. Fernstudieneinheit 4. Langenscheidt: Universität Gesamthochschule Kassel. 184 p.

Onalan, O. \& Çakır, A.A. (2018). Comparative Study on Speech Acts: Formal Complaints by Native Speakers and Turkish Learners of English. Eurasian Journal of Applied Linguistics. 4 (2). 239-259.

Order $\mathrm{N}^{\circ} 940$. On the approval of the state federal standard of higher education in the direction of linguistic training 45.03.02 (high school level), Ministry of Education and Science of the Russian Federation, of August 7, 2014. Recovered from: http://fgosvo.ru/uploadfiles/fgosvob/450302_Li ngvistika.pdf

Piepho, H.-E. (1979). Kommunikative Kompetenz durch Englischunterricht. Der Fremdsprachenunterricht. (Communicative competence through English lessons. Foreign language teaching) 4. 22-25.

Ponutrieva, V.P. (1997). Communicative skills of the teacher as a condition for enhancing the cognitive activity of the teacher (dissertation of the candidate of pedagogical sciences). Bryansk Pedagogic State University, Bryansk. 142 p. Recovered from: http://childpsy.ru/dissertations/id/19457.php

Rumyantseva, T.A. (1999). Teaching argumentation communication among students of the 3rd year of a language university, (abstract of thesis for the candidate of pedagogical sciences), Ural Federal University, Ekaterinburg. 24 p. Recovered from: http://www.dslib.net/teoria-

vospitania/obuchenie-argumentativnomuobweniju-studentov-3-kursa-jazykovogopedagogicheskogo.html

Safonova, V.V. (1992). Socio-cultural approach to teaching foreign languages as a specialty, (dissertation of the doctor of pedagogical sciences), Moscow State University, Moscow. 672 p. Recovered from: https://www.dissercat.com/content/sotsiokulturn yi-podkhod-k-obucheniyu-inostrannomuyazyku-kak-spetsialnosti

Smirnova, E.V. (1999). Development of the culture of foreign language communication (polylogue) in postgraduate education of teachers of foreign languages, (dissertation of the candidate of pedagogical sciences), Moscow State University, Moscow. 205 p. Recovered from:

https://www.dissercat.com/content/razvitiekultury-inoyazychnogo-polilogicheskogoobshcheniya-v-poslevuzovskom-obrazovaniipre

Solovova, E.N. (2002). Methods of teaching foreign languages. Basic course of lectures. A handbook for pedagogical students. universities and teachers. Moscow: Education. 239 p. Recovered from: http://learnteachweb.ru/articles/solovova1.pdf Sousa, A.A. (2017). Discourse-Based View in Interdisciplinary Approaches to Fictional Text Analysis. Russian Journal of Linguistics. 21(2). 390-404.

Stepanov, Yu.S. (1981). Seeking the pragmatics. Bulletin of the Academy of Sciences of the USSR. Series: literature. 40(4). 330-336.

Torricelli, P. (2018). Understanding pragmatics in second-language learning. A few linguistic preliminaries. in "Reti, saperi, linguaggi, Italian Journal of Cognitive Sciences". 1. 203-208.

Ulrich, W. (1979). Grundbegriffe des Deutschunterrichts. Verlag Ferdinand Hirt. 75 p. (aleman)

Volovik, A.V. (1988). Communicative approach to teaching foreign languages, (abstract of the dissertation for the candidate of pedagogical sciences), Moscow State university, Moscow. $23 \mathrm{p}$.

Zhoglina, G.G. (1998). Development of communicative competence skills based on the use of video films, (dissertation of the candidate of pedagogical sciences), Pyatigorsk State University, Pyatigorsk. 309 p. Recovered from: https://www.dissercat.com/content/razvitieumenii-kommunikativnoi-kompetentsii-naosnove-ispolzovaniya-autentichnykh-videodoku 